\title{
POLITYKA ADMINISTRACYJNA MINISTRÓW SPRAW WEWNĘTRZNYCH RZECZYPOSPOLITEJ POLSKIEJ W DZIEDZINIE APROWIZACJI I JEJ WPŁYW NA APROWIZACJĘ ARMII POLSKIEJ W LATACH 1918-1939
}

\section{Wprowadzenie}

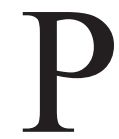

rzedmiotem niniejszego opracowania jest polityka administracyjna ministrów spraw wewnętrznych II Rzeczypospolitej (RP) w dziedzinie aprowizacji oraz jej wpływ na aprowizację armii polskiej w latach 1918-1939. W tym ujęciu kwestia zaopatrzenia Wojska Polskiego (WP) jest wtórna w stosunku do aprowizacji państwa jako takiego, gdyż armia była tylko jednym z podsystemów, składających się na system aprowizacyjny II RP. W konsekwencji, głównym celem niniejszego opracowania jest ukazanie polityki administracyjnej pańswa w zakresie aprowizacji, współrealizowanej przez resort spraw wewnętrznych wraz z Ministerstwem Aprowizacji w latach 1918-1921, realizowanej przez ten resort w latach 1921-1938, a następnie ponownie współrealizowanej przez niego z Ministerstwem Rolnictwa i Reform Rolnych w latach 1938-1939.

W pierwszej kolejności, należy wyjaśnić pojęcie polityki administracyjnej. Otóż, jest to - odwołująca się do racjonalnych założeń, programowa działalność organów administracji publicznej, realizowana w prawnie dozwolonych formach i sposobach działania. Na politykę tę zasadniczy wpływ wywiera czynnik pozaprawny, jakim jest szeroko rozumiane życie polityczne kraju. Poszczególne fazy tej polityki odpowiadają okresom dziejowym, charakterystycznym dla historii 
politycznej danego kraju. Fazy te występują w istocie niezależnie od tego, czy obowiązuje dotychczasowe ustawodawstwo, czy też ulega ono sukcesywnym zmianom i przekształceniom. Dla II RP były to fazy ujęte w następujących przedziałach czasowych (okresach): 1918-1926, 1926-1930, 1930-1935 i 1935-1939'.

Gdy chodzi o pojęcie „aprowizacja”, to w literaturze przedmiotu występuje wiele jego definicji. Większość $\mathrm{z}$ nich, zawiera jednak te same lub podobne desygnaty. Tak więc $\mathrm{w}$ aspekcie etymologicznym, aprowizacja (łac. $a d=$ do + provisio = przezorność, zapobiegliwość) $\mathrm{w}$ języku polskim to: 1. zaopatrywanie ludności w artykuły pierwszej potrzeby (zwłaszcza żywność); 2. potocznie: artykuły żywnościowe, żywność ${ }^{2}$. Natomiast $\mathrm{w}$ aspekcie ekonomicznym - aprowizacja to: zaopatrywanie ludności w środki żywnościowe pierwszej potrzeby. Rola państwa w zakresie aprowizacji polega nie tylko na działaniu w sferze obrotu artykułami spożywczymi, lecz także w pewnym zakresie ich produkcji i transportu, najczęściej w okresach niedoboru artykułów żywnościowych oraz spekulacji związanej z przerwaniem normalnego toku życia gospodarczego, szczególnie podczas wojny lub w jej wyniku. Przeciwdziałając tym zjawiskom, państwo prowadzi reglamentację środków żywnościowych, często przejmując monopol obrotu i stosując system zaopatrzenia kartkowego ${ }^{3}$.

\section{Polityka administracyjna ministrów spraw wewnętrznych w zakresie aprowizacji państwa w latach 1918-1926}

Politykę administracyjną resortu spraw wewnętrznych w zakresie aprowizacji państwowej w latach 1918-1926 (do zamachu majowego 1926 r.) prowadzili następujący ministrowie spraw wewnętrznych: Stanisław August Thugutt (17 lipca 1918 r. - 16 stycznia 1919 r.), Stanisław Wojciechowski (16 stycznia 1919 r. - 23 czerwca 1920 r.), Józef Kuczyński (23 czerwca - 24 lipca 1920 r.), Leopold Skulski (24 lipca 1920 r. - 28 czerwca 1921 r.), Władysław Raczkiewicz (28 czerwca - 19 września 1921 r.), Stanisław Józef Downarowicz (19 wreśnia 1921 r. - 10 marca 1922 r.), Antoni Kamieński (10 marca - 11 grudnia 1922 r.). Następnie, Ludwik Darowski (11-16 grudnia 1922 r.), Władysław Eugeniusz Sikorski (16 grudnia 1922 r. - 28 maja 1923 r.), Władysław Kiernik (28 maja - 19 grudnia 1923 r.), Władysław Sołtan (19 grudnia 1923 r. - 21 marca 1924 r.), Zygmunt Hübner (21 marca - 17 listopada 1924 r.), Cyryl Ratajski (17 listopada 1924 r. - 14 czerwca

\footnotetext{
${ }^{1}$ W. Kozyra, Polityka administracyjna ministrów spraw wewnętrznych Rzeczypospolitej Polskiej w latach 1918-1939, Lublin 2009, s. 24.

2 Stownik wyrazów obcych PWN, Warszawa 1978, s. 44.

${ }^{3}$ Encyklopedia Historii Gospodarczej Polski do 1945 roku, t. I, Warszawa 1981, s 17. Vide: L. URLIŃski, Polski plan aprowizacji wojennej we wrześniu 1939 roku, Toruń 2004, s. 16-19.
} 
1925 r.), Władysław Raczkiewicz (15 czerwca 1925 r. - 10 maja 1926 r.) i Stefan Smólski (10-15 maja 1926 r.) $)^{4}$.

W latach 1918-1921 szefowie resortu spraw wewnętrznych ściśle współpracowali z główną instytucją kraju do spraw aprowizacyjnych, to jest z Ministerstwem Aprowizacji. W latach 1918-1919 z ministerstwem tym przede wszystkim współdziałały - pod ogólnym nadzorem Ministerstwa Spraw Wewnętrznych (MSW) - struktury resortu spraw wewnętrznych, to jest komisarze ludowi (komisarze rządowi, starostowie), w których urzędach ulokowane były agendy terenowe Ministerstwa Aprowizacji - Referaty Aprowizacyjne. Przy referatach tych działały społeczne rady aprowizacyjne na czele z kierownikami administracji powiatowej. W konsekwencji, w okresie tym najważniejszymi instytucjami aprowizacyjnymi $\mathrm{w}$ administracji spraw wewnętrznych były referaty aprowizacyjne w urzędach komisarzy ludowych (rządowych), a następnie w urzędach starościńskich ${ }^{5}$. Tytułem przykładu przedstawię rozliczenie Referatu Aprowizacyjnego Kieleckiego z rozdziału zboża za okres od 1 września 1918 r. do 30 czerwca 1919 r. (tabela 1).

Tabela 1

Rozliczenie Referatu Aprowizacyjnego Kieleckiego z rozdziału zboża za okres: 1 wrzesień 1918 - 30 czerwiec 1919 r.

\begin{tabular}{|l|c|c|}
\hline \multicolumn{1}{|c|}{ Wyszczególnienie } & Przychód w kilogramach & Rozchód w kilogramach \\
\hline $\begin{array}{l}\text { Zboże pozostałe po } \\
\text { okupantach }\end{array}$ & 500,0 & 0,0 \\
\hline listopad 1918 & 24668,0 & 27379,5 \\
\hline grudzień & 34420,0 & 36814,5 \\
\hline styczeń 1919 & 69093,0 & 56433,5 \\
\hline luty & 68887,0 & 56705,5 \\
\hline marzec & 74254,0 & 57204,5 \\
\hline kwiecień & 59243,0 & 55362,5 \\
\hline
\end{tabular}

4 W. Kozyra, op. cit., s. 136-183.

5 Archiwum Państwowe w Kielcach (dalej: APK), Urząd Wojewódzki Kielecki, Wydział Organizacyjny, sygn. 68, Sprawozdanie Komisarza Ludowego w Kielcach za styczeń 1919 r., k. 22. 
Tabela 1 (cd.)

\begin{tabular}{|l|c|c|}
\hline \multicolumn{1}{|c|}{ Wyszczególnienie } & Przychód w kilogramach & Rozchód w kilogramach \\
\hline maj & 41530,0 & 41198,0 \\
\hline czerwiec & 41530,0 & 29912,0 \\
\hline Razem & 372595,0 & 361110,0 \\
\hline
\end{tabular}

Źródło: Archiwum Państwowe w Kielcach, Urząd Wojewódzki Kielecki, Wydział Organizacyjny, sygn. 76, k. 2, Rozliczenie Referatu Aprowizacyjnego Kieleckiego z rozdziału zboża za okres: 1 wrzesień 1918 r. - 30 czerwiec 1919 r., brak paginy.

Jak wynika $\mathrm{z}$ tabeli, najtrudniejsza sytuacja aprowizacyjna $\mathrm{w}$ powiecie kieleckim była w okresie od stycznia do kwietnia 1919 r.; podobnie było w całym kraju. Dlatego też, kierownictwo resortu spraw wewnętrznych postanowiło całościowo uporzadkować działający w jego ramach dział aprowizacyjny poprzez powołanie 2 września 1919 r. w Ministerstwie Spraw Wewnętrznych w Sekcji VI - Referatu Aprowizacyjnego. Zaczął on wydawać zarządzenia, okólniki, instrukcje zarówno podległym MSW organom terenowym (urzędom wojewódzkim i starościńskim), jak też nadzorowanym przez nie referatom aprowizacyjnym $w$ organach samorządu terytorialnego. W rezultacie, praca agend aprowizacyjnych w terenie uległa znaczącej poprawie ${ }^{6}$.

Zasadnicze zmiany strukturalne w zakresie organizacji i funkcjonowania administracji aprowizacyjnej w skali kraju zaszły w drugiej połowie $1921 \mathrm{r}$. Najpierw - 7 lipca Sejm uchwalił ustawę likwidującą odrębne Ministerstwo Aprowizacji, przekazując jego zasadnicze kompetencje $\mathrm{MSW}^{7}$. Następnie, ustawą z 17 grudnia potwiedzono, że z dniem 31 grudnia tego roku przestaje istnieć Ministerstwo Aprowizacji, a minister spraw wewnętrznych od 1 stycznia $1922 \mathrm{r}$. staje się naczelnym organem państwa w zakresie spraw aprowizacyjnych ${ }^{8}$. Akt ten przekazał dotychczasowy aparat aprowizacyjny państwa (podległy dotąd Ministerstwu Aprowizacji) - MSW. Odtąd też podstawowym zadaniem resortu spraw wewnętrznych było gromadzenie i rodział żywności w skali kraju (w tym dla wojska) oraz nadzór nad głównymi przedsiębiorstwami przemysłu rolno-spożywczego. Oprócz administracji spraw wewnętrznych, wybrane zagadnienia apro-

${ }^{6}$ Ibidem, k. 22-24.

7 Dziennik Ustaw 1921, nr 63, poz. 389, Ustawa z 7 VII 1921 r. o zniesieniu ograniczeń w zakresie obrotu ziemiopłodami oraz o postawieniu Ministerstwa Aprowizacji w stan likwidacji.

${ }^{8}$ Dziennik Ustaw 1921, nr 106, poz. 774, Ustawa z 17 XII 1921 r. w przedmiocie przekazania czynności Ministerstwa Aprowizacji. 
wizacyjne znalały się w gestii jeszcze innych resortów. Były to: Ministerstwo Rolnictwa i Dóbr Państwowych - od 1932 r. Ministerstwo Rolnictwa i Reform Rolnych w odniesieniu do produkcji rolnej, spraw hodowlanych i rybołóstwa śródlądowego oraz części przemysłu spożywczego; Ministerstwo Przemysłu i Handlu - w dziedzinie przemysłu spożywczego, rybołówstwa morskiego, importowanych artykułów spożywczych i używek oraz surowców mineralnych; Ministerstwo Skarbu - w zakresie artykułów monopolowych, niektórych surowców mineralnych i częściowo spraw przemysłu pracującego na potrzeby aprowizacji kraju'. Okres przebudowy administracji aprowizacyjnej w ramach resortu spraw wewnętrznych zamknął okólnik nr 29 ministra spraw wewnętrznych Stanisława Downarowicza z 15 lutego 1922 r., który powoływał w Departamencie Samorządowym MSW - Wydział Aprowizacyjny. Obejmował on wszystkie sprawy, dotyczące aprowizacji w zakresie MSW, z wyjątkiem spraw rekursów karno-aprowizacyjnych, które załatwiane były przez Wydział Administracyjno-Karny MSW. W szczególności do Wydziału Aprowizacyjnego należały: sprawy walki z lichwą, badania cen i zysków oraz ustalania cen wytycznych, sprawy związane $\mathrm{z}$ wykonywaniem ustawy o obrocie towarowym $\mathrm{z}$ zagranicą, sprawy ewidencji popytu, podaży, produkcji, zapotrzebowania i cen przedmiotów pierwszej potrzeby uzgadniane w porozumieniu z Ministerstwem Przemysłu i Handlu, Rolnictwa i Dóbr Państwowych oraz Głównym Urzędem Statystycznym. Następnie sprawy wynikające z kontroli wykorzystania kredytów Skarbu Państwa na zakup zboża, sprawy aprowizacji Górnego Śląska, nadzór nad polityką aprowizacyjną organów samorządowych, sprawy kontyngentu na kresach wschodnich ${ }^{10}$.

Już jednak rozporządzeniem Rady Ministrów z 12 lipca 1923 r., Wydział Aprowizacyjny MSW wraz z całym pionem administracji aprowizacyjnej wyłączono $\mathrm{z}$ jednolitych struktur resortu spraw wewnętrznych i podporządkowano - formalnie podległemu ministrowi spraw wewnętrznych - działającemu od 1 lutego 1923 r., nadzwyczajnemu komisarzowi do zwalczania drożyzny ${ }^{11}$. Lecz już w dniu 3 marca 1924 r. urząd wspomnianego komisarza uległ likwidacji, a Wydział Aprowizacyjny ponownie włączono w skład Departamentu Samorządowego MSW, natomiast podległa mu administracja aprowizacyjna $\mathrm{w}$ terenie weszła $\mathrm{w}$ skład struktur administracji spraw wewnętrznych. W tym czasie uprawnienia ministra spraw wewnętrznych $\mathrm{w}$ zakresie zagadnień aprowizacji państwa obejmowały pieczę nad stanem zaopatrzenia ludności w artykuły żywnościowe i inne przedmioty powszechnego użytku, zwalczanie lichwy oraz nadzór nad gospodarką aprowizacyjną związków komunalnych. W terenie

\footnotetext{
9 L. URLIŃSKI, op. cit., s. 47.

${ }_{10}$ Dziennik Ustaw MSW 1922, nr 3, poz. 82, Okólnik MSW nr 29 z 15 II 1922 r.

${ }_{11}$ Dziennik Ustaw MSW 1923, nr 5, poz. 99, Okólnik MSW nr 88 z 25 VII 1923 r.
} 
zagadnienia aprowizacyjne były realizowane przez organy administracji ogólnej oraz samorządu terytorialnego, jako jego zadania zlecone ${ }^{12}$.

Od przełomu lat 1921-1922 polityka administracyjna szefów MSW w zakresie aprowizacji kraju koncentrowała się nie tyle na zwiększaniu towarów pierwszej potrzeby na rynku, ile na wzrastających cenach (drożyźnie) oraz związanym z tym paskarstwem i lichwą. Już w marcu $1921 \mathrm{r}$. minister spraw wewnętrznych L. Skulski w imieniu rządu przedstawił sejmowi kroki, jakie chciał podjąć, by ukrócić wzrastającą drożyznę. Struktury administracyjno-policyjne poczęły uderzać w paskarzy (nieuczciwych pośredników). Z raportu Komisariatu Rządu m. st. Warszawy wynikało, że na dzień 1 marca 1921 r. ponad 30 osób było z tego powodu internowanych, zaś na szeroką skalę prowadzono również „akcję śledczą”. Rząd zdecydowany był działalność tę kontynuować, gdyż uważał, iż „[...] poza przyczynami natury czysto ekonomicznej, od których oczywiście ceny zależą, niesłychany cynizm w podbijaniu cen również dominującą rolę odgrywa"13. Mimo tych działań, drożyzna w 1922 r. wzrastała nadal, a jej apogeum przypadło na okres hiperinflacji w drugiej połowie $1923 \mathrm{r}$. W tym czasie rząd i minister spraw wewnętrznych podjęli wiele przedsięwzięć, by negatywne skutki drożyzny maksymalnie ograniczyć. W początkach 1923 r. szef resortu wysłał do podległych sobie władz okólnik $W$ sprawie zwalczania drożyzny i pośredników. W lutym powołano wspomniany wyżej urząd nadzwyczajnego komisarza do zwalczania drożyzny, na czele którego stanął Tadeusz Hertleb. Wydano specjalne zarządzenie z wykazem kar nakładanych na osoby, które naruszały przepisy przeciwko drożyźnie, a pod koniec 1923 r. ukazał się okólnik MSW w sprawie zwalczania lichwy. Już jednak wiosną następnego roku, po wprowadzeniu reformy walutowej Władysława Grabskiego, problem drożyzny przestawał być palący, czego dowodem była - wspomniana wcześniej - likwidacja stanowiska nadzwyczajnego komisarza do zwalczania drożyzny ${ }^{14}$.

Od drugiej połowy 1924 r. zaczęły pojawiać się ponownie trudności w nabyciu podstawowych produktów żywnościowych. Stąd też, we wrześniu tego roku odbyła się konferencja w MSW w sprawie zaopatrzenia miasta st. Warszawy w mięso i jego przetwory. Większe perturbacje w zakresie aprowizacyjnym pojawiły się również jesienią 1925 r., w związku z kryzysem wynikającym

12 Archiwum Akt Nowych (dalej: AAN), MSW, Gabinet Ministra Wydział Organizacyjno-Prawny, sygn. 477, Likwidacja stanowiska nadzwyczajnegokomisarza do spraw zwalczania drożyzny, k. 174; APK, Urząd Wojewódzki Kielecki, Wydział Organizacyjny, sygn. 26, Zmiany organizacyjne w MSW k. 13; R. Hausner, Pierwsze dwudziestolecie administracji spraw wewnętrznych, Warszawa 1939, s. 40-42, 125.

${ }_{13}$ Biblioteka Sejmowa, Sejm Ustawodawczy, Sprawozdanie stenograficzne nr 214 z 1 III 1921, p. 23-24, Wystąpienie premiera L. Skulskiego.

${ }^{14}$ R. Hausner, op. cit, s. 197. 
z załamania się kursu złotego. Największe niedobory ujawniły się na rynku zbożowym. W związku z tym, MSW - w porozumieniu z Ministerstwem Rolnictwa i Dóbr Państwowych - rozpoczęło tworzyć państwowe rezerwy zbożowe, dzięki czemu bardzo szybko ceny zboża ustabilizowały się, i to na dość niskim poziomie. W tym czasie prowadzono na szeroką skalę kontrole piekarń prywatnych, samorządowych i spółdzielczych przez powołane w tym celu wojewódzkie i powiatowe komisje do badania jakości chleba. Odpowiedzialnymi za właściwą realizację zarządzeń tych komisji były przede wszystkim samorządy miejskie i powiatowe związki komunalne ${ }^{15}$.

\section{Polityka administracyjna ministrów spraw wewnętrznych w zakresie aprowizacji państwa w latach 1926-1930}

Po zamachu majowym 1926 r., do władzy doszedł marszałek Józef Piłsudski i jego zwolennicy, którzy szybko zorganizowali się w odrębny obóz polityczny, nazywany piłsudczykowskim, legionowym czy też sanacyjnym. Piłsudczycy w znaczącym stopniu zmienili dotychczasową politykę administracyjną resortu spraw wewnętrznych, co również szybko dało się zauważyć w działaniach MSW na polu aprowizacyjnym ${ }^{16}$. W tym czasie ministrami spraw wewnętrznych byli: Kazimierz Młodzianowski (15 maja - 2 października 1926 r.), Sławoj Felicjan Składkowski (2 października 1926 r. - 29 grudnia 1929 r.), Henryk Józewski (29 grudnia 1929 r. - 3 czerwca 1930 r.) ${ }^{17}$. Wszyscy oni prowadzili ożywioną politykę administracyjną na polu aprowizacyjnym. W wyniku reorganizacji MSW przeprowadzonej 1 lipca 1926 r., Wydział Aprowizacyjny został przekształcony w Referat Aprowizacyjny i włączony do Wydziału Społeczno-Gospodarczego Departamentu Samorządu MSW. Bardzo szybko okazało się, że sprawy aprowizacyjne są zbyt ważne, by wtłoczyć je do samorządowych spraw społeczno-gospodarczych. Dlatego też, już 29 sierpnia 1927 r. kwestie aprowizacji państwa zostały wydzielone z Departamentu Samorządu i ulokowane w odrębnej komórce organizacyjnej, jaką był Samodzielny Wydział Aprowizacyjny, podporządkowany bezpośrednio podsekretarzowi stanu MSW ${ }^{18}$.

Samodzielny Wydział Aprowizacyjny obejmował: nadzór nad stanem zaopatrzenia ludności w artykuły żywnościowe i inne przedmioty powszechnego użytku w myśl ustaw, przekazujących odnośne kompetencje ministrowi spraw

${ }^{15}$ Archiwum Państwowe w Lublinie (dalej: APL), Urząd Wojewódzki Lubelski, Wydział Ogólny, sygn. 269, Sprawozdanie Wojewódzkiej Komisji do Badania Chleba za 1925 r., k. 22; W. KozYrA, Urząd Wojewódzki w Lublinie w latach 1919-1939, Lublin 1999, s. 304.

16 Vide: W. Kozyra, Polityka administracyjna..., s. 334-336.

17 Ibidem, s. 183-195.

18 Dziennik Ustaw MSW 1927, nr 3-4, poz. 54, Okólnik MSW nr 174 z 7 X 1927 r. 
wewnętrznych, zwalczanie lichwy, nadzór nad gospodarką aprowizacyjną związków komunalnych oraz sprawy mobilizacji gospodarczej dla celów wojskowych. W szczególności do Wydziału Aprowizacyjnego należały: 1) ogólna piecza nad aprowizacją ludności, przede wszystkiem mieszkańców miast i ośrodków przemysłowych oraz opracowywanie i ustalanie w porozumieniu z zainteresowanemi ministerstwami wytycznych państwowej polityki aprowizacyjnej; 2) piecza nad zaopatrzeniem ludności w zboża chlebowe, mąkę i pieczywo (sprawy obrotu zbożem w kraju i zagranicą, rezerw zbożowych, elewatorów zbożowych, normalizacji przemiału i wypieku, modernizacji piekarstwa); 3) piecza nad zaopatrzeniem ludności w mięso i tłuszcze (sprawy kas targowych, rzeźni, chłodni itp. w zakresie aprowizacyjnym); 4) piecza nad zaopatrzeniem ludności w inne przedmioty powszedniego użytku (sprawy polityki celnej w tym zakresie, taryf kolejowych, obrotu towarowego z zagranicą itp.), przede wszystkim w cukier i węgiel, załatwianie spraw wynikających $\mathrm{z}$ udzialu ministra spraw wewnętrznych w Komitecie Celnym i Państwowej Radzie Kolejowej; 5) ogólny nadzór nad poziomem cen przedmiotów powszedniego użytku w kraju (instruowanie i nadzór nad dzialalnością władz administracyjnych w dziedzinie zwalczania lichwy oraz władz komunalnych z zakresu zabezpieczenia podaży przedmiotów powszechnego użytku); 6) wykonywanie ustawodawstw w zakresie kompetencji ministra spraw wewnętrznych $\mathrm{w}$ dziedzinie ochrony lokatorów; 7) współpraca $\mathrm{z}$ Wydziałem Komunalnej Polityki Gospodarczej MSW w zakresie nadzoru nad dzialalnością aprowizacyjną związków komunalnych (sprawy miejskich przedsiębiorstw aprowizacyjnych, sprawy targów i jarmarków); 8) zbieranie, w porozumieniu z Głównym Urzędem Statystycznym, materiałów statystycznych w zakresie aprowizacji, jak też materiałów obrazujących w ogóle stosunki aprowizacyjne w państwie i zagranicą (badanie nowoczesnych metod produkcji artykułów żywnościowych oraz najlepszego wykorzystania produkcji tych artykułów); 9) współdziałanie z właściwymi ministerstwami, bankami państwowymi, związkami spółdzielczymi itp. w zakresie aprowizacji ludności; 10) załatwianie spraw związanych z Radą Spożywców i prowadzenie Sekretariatu tej Rady; 11) załatwianie spraw związanych z udziałem ministra spraw wewnętrznych w Komitecie Ekonomicznym Rady Ministrów z udzialem delegatów ministra spraw wewnętrznych w Komisji do badania kosztów utrzymania Komisji Ankietowej itp.; 12) sprawy mobilizacji żywnościowej w porozumieniu z Naczelnikiem Wydziału Wojskowego MSW stosownie do specjalnych zarządzeń w tym względzie ${ }^{19}$.

$\mathrm{W}$ tym momencie ranga zagadnień aprowizacyjnych $\mathrm{w}$ resorcie wzrosła w sposób zasadniczy. Na szczeblu wojewódzkim funkcjonowały w wydziałach

${ }_{19}$ Ibidem; Monitor Polski 1927, nr 209, poz. 209, Uzupetnienie Statutu Organizacyjnego Ministerstwa Spraw Wewnętrznych zatwierdzonego rozporządzeniem Rady Ministrów z dnia 29 VIII 1927 r. 
samorządowych, a w województwach zachodnich również w wydziałach administracyjnych - oddziały aprowizacyjne. Natomiast referaty aprowizacyjne działały w starostwach oraz w poszczególnych organach samorządu terytorialnego, zwłaszcza w zarządach miast wydzielonych ${ }^{20}$.

W latach 1926-1930 na pracę Samodzielnego Wydziału Aprowizacyjnego MSW i podległego mu aparatu administracyjno-samorządowego zasadniczy wpływ wywierały stałe braki zboża chlebowego, mimo że Polska była krajem rolniczym. Obliczono, że gdyby w Polsce utrzymał się przyrost naturalny z lat 1918-1928, to w 1938 r. zabrakłoby około 2,5 mln ton zbóż. Dlatego też, Samodzielny Wydział Administracyjny MSW rozpoczął ścisłą współpracę z Ministerstwem Rolnictwa i Dóbr Państwowych w sprawie wzrostu krajowej produkcji rolniczej. Dużo sił i środków włożono w to, by ludność kraju zaopatrywała się w możliwie tani i dobry chleb. W związku z tym, kierownictwo MSW rozpoczęło ścisłą współpracę z trzema wyspecjalizowanymi komisjami rządowymi, to jest: Międzyministerialną Komisją Państwowej Rezerwy Zbożowej, Komisją Normalizacji i Przemiału Zbożowego, Ogólnopaństwową Komisją Badania Chleba. Pierwsza z nich, nadzorowała zakup i magazynowanie odpowiedniej ilości zbóż (pszenicy i żyta) oraz zabezpieczała potrzeby zbożowe rynku wewnętrznego. Akcję zakupu zbóż prowadził Państwowy Bank Rolny. Do końca roku budżetowego 1928/1929 z kredytów państwowych przeznaczonych na stworzenie Państwowej Rezerwy Zbożowej, wyasygnowano kwotę 12,8 mln zł, którą przeznaczono na zwiększenie rezerwy zbożowej w największych ośrodkach miejsko-przemysłowych kraju. Z kwoty tej najwięcej otrzymała Warszawa - 5000000 zł (39,9\%). Dzięki Państwowej Rezerwie Zbożowej w takich ośrodkach przemysłowych, jak Warszawa, Łódź, Poznań, obszar Górnego Śląska itp. - wiosną 1928 r. cena $1 \mathrm{~kg}$ chleba ustabilizowała się na poziomie 70 groszy. Działalność Samodzielnego Wydziału Aprowizacyjnego i Komisji Normalizacji i Przemiału Zbożowego obejmowała sprawy organizacji i funkcjonowania przemysłu młynarskiego i piekarskiego. Komisja Normalizacji i Przemiału Zbożowego ustaliła standardową ocenę jakości zboża, mąki i wypiekanego chleba oraz opracowała „mapę chlebową Polski”, w której wyróżniono 6-8 regionów. Dnia 30 sierpnia 1927 r. minister spraw wewnętrznych, S.F. Składkowski, biorąc pod uwagę ustalenia tej komisji, wydał zarządzenie ograniczające możliwość dowolnego przemiału mąki, co w rezultacie spowodowało zwiększenie jej podaży na rynku ${ }^{21}$.

${ }^{20}$ AAN, MSW, Gabinet Ministra Wydział Organizacyjno-Prawny, sygn. 27, Organizacja Samodzielnego Wydziału Aprowizacyjnego, k. 54; R. Hausner, op. cit., s. 42-43; S. Szwalbe, Państwowa polityka aprowizacyjna w zakresie zbożowym, Warszawa 1928, s. 3-6.

${ }^{21}$ Ibidem, sygn. 707, Sprawozdanie Samodzielnego Wydziału Aprowizacyjnego za 1928 r., k. 669-673; Monitor Polski 1927, nr 177, poz. 49. 
Administracja aprowizacyjna MSW ściśle współpracowała z Ogólnopaństwową Komisją Badania Chleba w celu podniesienia stanu sanitarnego piekarń i ich mechanizacji, dzięki czemu 16 kwietnia 1928 r. ukazało się rozporządzenie ministra S.F. Składkowskiego w sprawie powołania wojewódzkich komisji badania chleba, które na terenie swoich województw oprócz - okręgowych komisji badania chleba - przeprowadzały kontrole piekarń i badały jakość wypiekanego chleba. W 1928 r. podczas przeprowadzonej kontroli przez wojewódzkie komisje badania chleba, stwierdzono, iż spośród 572 sprawdzonych piekarni - w 60 panował zły stan techniczno-sanitarny, w 259 stan określono jako średni, zaś w 253 jako dobry. Organy aprowizacyjne $\mathrm{w}$ terenie i wojewódzkie komisje badania chleba działały na rzecz mechanizacji piekarń. Za ich pośrednictwem znaczna ilość tych zakładów otrzymała dofinansowanie ze strony państwa. W 1928 r., powstały samorządowe piekarnie mechaniczne w Krakowie, Czechowicach na Śląsku i w Warszawie. Oprócz nich, dofinansowano jeszcze 10 piekarń spółdzielczych i prywatnych. Samodzielny Wydział Aprowizacyjny pracował na rzecz podniesienia poziomu aprowizacji ludności kraju w mięso i jego przetwory. Dlatego też, współdziałał z szeregiem instytucji państwowych i samorządowych na rzecz utworzenia w Warszawie takich instytucji gospodarczych jak: Giełda Mięsna, Kasa Targowa i Targowica Centralna, które miały rozpocząć działalność wiosną 1929 r. ${ }^{22} \mathrm{~W}$ celu zaopatrzenia Warszawy w mięso odpowiedniej jakości Samodzielny Wydział Aprowizacyjny MSW doprowadził do współpracy między Miejskimi Zakładami Zaopatrzenia m. st. Warszawy a Mięsną Spółdzielnią Wytwórczą w Wołkowysku. W ścisłym związku ze sprawą zaopatrywania ludności $\mathrm{w}$ mięso, ale również $\mathrm{w}$ nabiał i jaja, było przygotowanie planu budowy nowoczesnych chłodni w głównych ośrodkach przemysłowych kraju (w tym czasie w Gdyni budowano jedną z największych chłodni w Europie).

Administracja aprowizacyjna walczyła ze zbyt wygórowanymi cenami przedmiotów powszechnego użytku, bazując na ustawie o zwalczaniu lichwy wojennej i ustawie o zabezpieczeniu podaży przedmiotów powszechnego użytku. Komórka aprowizacyjna MSW była w stałym kontakcie ze społecznymi czynnikami gospodarczymi oraz z Państwową Radą Spożywców, działającymi na rzecz podniesienia jakości aprowizowania ludności kraju w podstawowe produkty spożywcze. Utrzymywała kontakty z organizacjami rolniczymi, a jej przedstawiciele brali aktywny udział w pracach Towarzystwa Polityki Administracyjnej. W jego Sekcji Aprowizacyjnej analizowano w sposób naukowy zagadnienia aprowizacji państwa. W tym czasie, tak charakteryzowano działalność Samodzielnego Wydziału Aprowizacyjnego MSW:

${ }^{22}$ Ibidem, k. 647-648; R. Macyra, Na rynku hossy i bessy. Giełdy towarowe w II Rzeczypospolitej, Poznań 2004, s. 8-15. 
Z jednej strony znajdując się w ścisłym kontakcie z organizacjami konsumentów i producentów, z drugiej zaś [...] opierając się na naukowych badaniach ekonomicznych dąży do tego, by zarządzenia Rządu z dziedziny aprowizacyjnej miały przemyślany charakter i zgodny z teorią środków polityki gospodarczej oraz by były zrozumiałe przez szerokie warstwy społeczeństwa ${ }^{23}$.

\section{Polityka administracyjna ministrów spraw wewnętrznych w zakresie aprowizacji państwa w latach 1930-1935}

W pierwszej połowie lat trzydziestych, w okresie wielkiego kryzysu gospodarczego (1929-1935), zagadnienia aprowizacji państwa w coraz większym stopniu absorbowały politykę administracyjną ministrów spraw wewnętrznych. W tym okresie funkcję szefów resortu spraw wewnętrznych sprawowali: Sławoj Felicjan Składkowski (3 czerwca 1930 r. - 22 czerwca 1931 r.), Bronisław Wilhelm Pieracki (23 czerwca 1931 r. - 15 czerwca 1934 r.), Leon Kozłowski (15-28 czerwca 1934 r.) i Marian Zyndram-Kościałkowski (28 czerwca 1934 r. - 13 października 1935 r.) $)^{24}$. W ramach MSW kwestiami aprowizacyjnymi w dalszym ciągu zajmował się Samodzielny Wydział Aprowizacyjny, nadzorując pracę jednostek aprowizacyjnych w terenie, skupionych w urzędach administracji ogólnej i samorządu terytorialnego. W tym czasie, struktury administracji aprowizacyjnej wzmocniono organizacyjnie i kadrowo. W dniu 25 czerwca 1932 r. Samodzielny Wydział Aprowizacyjny został rozbudowany i przekształcony w Biuro Aprowizacyjne MSW ${ }^{25}$. W znowelizowanym Statucie Organizacyjnym MSW z 25 czerwca 1932 r. tak ujęto jego kompetencje:

Biuro Aprowizacyjne obejmuje sprawy pieczy nad stanem zaopatrzenia ludności w artykuły żywnościowe i inne przedmioty powszechnego użytku, zwalczanie lichwy, nadzór nad gospodarką aprowizacyjną związków komunalnch, sprawy mobilizacji gospodarczej dla celów wojskowych ${ }^{26}$.

W okresie wielkiego kryzysu gospodarczego, głównym celem ministrów spraw wewnętrznych i podległej im administracji aprowizacyjnej, było działanie na rzecz obniżenia kosztów utrzymania szerokich rzesz ludności. Dlatego też, Oddział Aprowizacyjny w Urzędzie Wojewódzkim Lubelskim, wspólnie z władzami administracyjnymi pierwszej instancji i organami samorządu terytorialnego,

${ }^{23}$ Ibidem, k. 674-680; K. Orzechоwsкi-Oкsza, Uwagi ogólne w sprawie techniki mielenia zbóż chlebowych, Warszawa 1928, s 10-16.

${ }^{24}$ W. Kozyra, Polityka administracyjna..., s. 195-212.

${ }^{25}$ Monitor Polski 1932, nr 148, poz. 182, Uchwała Rady Ministrów z dnia 25 VI 1932 r. w sprawie statutu organizacyjnego Ministerstwa Spraw Wewnętrznych; R. HAusner, op. cit., s. 44.

${ }^{26}$ Monitor Polski 1932, nr 148, poz. 182, Załącznik do Uchwały Rady Ministrów z 25 VI 1932 - Statut Organizacyjny Ministerstwa Spraw Wewnętrznych, $\$ 9$. 
czuwał nad cenami i podażą przedmiotów powszechnego użytku tak, by poziom tych cen „był zawsze słuszny co do rzeczywistej wartości”. Były one ustalane przez specjalne komisje, w skład których wchodzili przedstawiciele administracji rządowej (aprowizacyjnej), sfer pracowniczych i przedsiębiorców z poszczególnych branż. W rezultacie, w latach 1932-1935 w województwie lubelskim dokonano trzykrotnej obniżki cen mięsa i jego przetworów, dzięki zmniejszeniu opłat za ubój, ubój rytualny i mięso na placach targowych. Na zmniejszenie to miało też wpływ utworzenie, przy współudziale administracji aprowizacyjnej, giełdy mięsnej w Lublinie, która wyeliminowała znacznym stopniu dominujące dotąd rozdrobnione pośrednictwo handlowe, wpływające na wzrost cen detalicznych mięsa i jego przetworów. Od 1934 r. prawie 70\% mięsa skierowanego na eksport i 40\% mięsa zakupionego przez rzeźników lubelskich pochodziło z tej giełdy. Jej obrót w 1934 r. wynosił $7 \mathrm{mln}$ zł, a w roku następnym już 7,8 mln zł. Oddział Aprowizacyjny Urzędu Wojewódzkiego Lubelskiego współdziałał również w udzielaniu pomocy przymierającej głodem ludności miejskiej, poprzez prowadzenie rozdawnictwa zboża i mąki. W latach 1934-1935 wydano 807 rodzinom w formie pomocy bezzwrotnej i 11896 rodzinom w zamian za „odrobek” przy robotach publicznych - 18184 kwintali żyta i 2050 kwintali mąki żytniej o ogólnej wartości 291280 zł².

Po kilku latach funkcjonowania Biura Aprowizacyjnego MSW i dotychczasowych struktur aprowizacyjnych w terenie, w Prezydium Rady Ministrów i kierownictwie resortu spraw wewnętrznych rozpoczęła się dyskusja nad nowym ich usytuowaniem w strukturze administracyjnej państwa. Uważano, że dotychczasowy zakres działania ministra spraw wewnętrznych w sprawach aprowizacyjnych, obejmujący nadzór nad stanem zaopatrzenia ludności w artykuły żywnościowe i inne przedmioty powszechnego użytku, zwalczanie lichwy, nadzór nad gospodarką aprowizacyjną związków komunalnych oraz sprawy mobilizacji gospodarczej dla celów wojskowych, obejmował splot zagadnień o charakterze gospodarczym, pozostających $\mathrm{w}$ nader ścisłym związku $\mathrm{z}$ działalnością resortu rolnictwa i reform rolnych oraz przemysłu i handlu. Zwracano uwagę i na to, że ustawa z 17 grudnia 1921 r., przekazująca zakres działań ministra aprowizacji szefowi MSW, nie określiła w sposób ścisły jego uprawnień aprowizacyjnych. Uznano więc, że należy teraz kompetencje te uściślić, a następnie przekazać poszczególne działy aprowizacyjne właściwym resortom. W wyniku tej dyskusji, MSW przygotowało projekt rozporządzenia Prezydenta RP O ustaleniu zakresu działania w sprawach aprowizacyjnych, który został 6 marca 1934 r. przyjęty przez Radę Ministrów. Zakładał on przekazanie kompetencji ministra spraw wewnętrznych

27 APL, Urząd Wojewódzki Lubelski, Wydział Samorządowy, sygn. 28, Działalność Wydziału Samorządowego w latach 1934-1935, k. 88 oraz Wydział Organizacyjny, sygn. 272, Działalność Giełdy Mięsnej w Lublinie w 1934 r., k. 74-75; S. Śliwa, Przemysł młynarski w Polsce, Poznań 1935, s. 11-19. 
w sprawach aprowizacyjnych ministrowi rolnictwa i reform rolnych oraz ministrowi przemysłu i handlu, gdyż to właśnie ci ministrowie skupiali w swych rękach $\mathrm{w}$ istocie wszystkie sprawy dotyczące produkcji rolnej, względnie przemysłowej. Mogli w sposób bardziej skoordynowany, niż to robił minister spraw wewnętrznych, oddziaływać na łagodzenie tych wszystkich sprzeczności, jakie wytwarzała „[...] rozbieżność interesów produkcji i spożycia, pogłębiona przeżywaniem przez cały świat kryzysem i zachwianiem się równowagi między podażą a popytem"28.

Do dyskusji nad nowymi zadaniami i kształtem organizacyjnym administracji aprowizacyjnej, włączyli się wojewodowie. Szef Urzędu Wojewódzkiego Pomorskiego, Stefan Kirtiklis, w piśmie do MSW z 13 lutego 1935 r. proponował wyłączenie spraw aprowizacyjnych $\mathrm{z}$ wydziałów samorządowych urzędów wojewódzkich, gdyż ulokowane w nich referaty aprowizacyjne koncentrowały się głównie na sprawach mobilizacji żywnościowej w związku z przygotowaniami administracji do obrony państwa. Były to zagadnienia z zakresu spraw wojskowych sensu stricto. Niestety, bardzo pożyteczna działalność Biura Aprowizacyjnego MSW w dziedzinie polityki cen, zwłaszcza nafty, owoców cytrusowych, cukru itp. w terenie - skutkiem wadliwego ulokowania referatu aprowizacyjnego w urzędach wojewódzkich „nie tylko nie przyczyniła się do posuwania spraw naprzód”, lecz powodowała „spotęgowanie chaosu”. Wojewoda pomorski proponował więc zlikwidowanie referatów aprowizacyjnych w wydziałach samorządowych urzędów wojewódzkich i utworzenie w ich miejsce referatów mobilizacyjno-żywnościowych w wydziałach wojskowych. Natomiast w dalszym ciągu wydziały przemysłowe winny przesyłać materiały statystyczno-aprowizacyjne do Biura Aprowizacyjnego $\mathrm{MSW}^{29}$. Szef resortu spraw wewnętrznych, przygotowując rozporządzenie z 6 marca 1934 r., opracował również nowelizację statutu podlegającego mu najważniejszego przedsiębiorstwa aprowizacyjnego w kraju, to jest „Państwowych Zakładów Przemysłowo-Zbożowych” z siedzibą w Lublinie. Zapisano w niej, że ich organem zwierzchnim jest odtąd minister rolnictwa i reform rolnych. Poza tym, nowy statut przewidywał zmniejszenie Rady Administracyjnej tych zakładów do 7 członków, przy jednoczesnym zwiększeniu jej części urzędniczej z 3 do 4 członków. Tym nowym członkiem był delegat Prezydium Rady Ministrów „Z uwagi na konieczność bardziej bezpośredniego oddziaływania na politykę interwencyjną PZP-Z, tego organizmu państwowego w ręku którego koncentrują się wszystkie nici polityki gospodarczej rządu”. Komisja Rewizyjna

${ }^{28}$ AAN, MSW, Gabinet Ministra Wydział Organizacyjno-Prawny, sygn. 477, Projekt Rozporządzenia Prezydenta RP „O ustaleniu zakresu działania w sprawach aprowizacyjnych”, przyjęty przez Radę Ministrów w dniu 6 III 1934 r., k. 174-176; W. Kozyra, Polityka administracyjna..., s. 495.

${ }_{29}$ Ibidem, sygn. 29, Pismo wojewody pomorskiego Stefana Kirtiklisa do MSW z 13 II 1935 r., k. $78-80$. 
Zakładów miała składać się z trzech członków powołanych przez Ministerstwo Rolnictwa i Reform Rolnych, z których jeden miał być mianowany w porozumieniu $\mathrm{z}$ ministrem skarbu ${ }^{30}$.

Ta zasadnicza reforma zagadnień aprowizacyjnych nie została ostatecznie wcielona w życie. Powodów tego stanu rzeczy było kilka, ale do najważniejszych zaliczyć należy kontrowersje, jakie wystąpiły między zainteresowanymi ministerstwami, co do zakresu przyznanych im kompetencji. Następnie, nieporozumienia między nimi a organami administracji ogólnej w sprawie form organizacji i funkcjonowania administracji aprowizacyjnej w terenie. W konsekwencji, Biuro Aprowizacyjne nadal działało w ramach MSW. Utrzymane zostały też dotychczasowe struktury administracji aprowizacyjnej w terenie ${ }^{31}$.

\section{Polityka administracyjna ministrów spraw wewnętrznych w zakresie aprowizacji państwa w latach 1935-1939}

W ostatnich latach przez II wojną światową polityką administracyjną resortu spraw wewnętrznych w zakresie aprowizacji kierowali: Władysław Raczkiewicz (13 października 1935 r. - 15 maja 1936 r.) oraz Sławoj Felicjan Składkowski (16 maja 1936 r. - wrzesień 1939 r. $)^{32}$. W tym czasie koncentrowali się oni przede wszystkim na wzmocnieniu państwowej rezerwy aprowizacyjnej (w szczególności zbożowej) oraz na zwalczaniu nieuzasadnionych podwyżek cen (drożyzny) artykułów powszechnego użytku. Formalnie rzecz ujmując, politykę tę wykonywali do 22 lutego 1938 r., kiedy to ukazał się dekret Prezydenta RP O przekazaniu spraw aprowizacyjnych Ministrowi Rolnictwa i Reform Rolnych. W konsekwencji, Biuro Aprowizacyjne w MSW uległo likwidacji, a w gestii ministra spraw wewnętrznych pozostały jedynie sprawy ochrony lokatorów i Komitetu Ekonomicznego Ministrów, które włączono do Departamentu Samorządu ${ }^{33}$.

W latach 1935-1938 ministrowie spraw wewnętrznych prowadzili regularny skup zboża, głównie chlebowego, dzięki czemu zasoby rezerwy aprowizacyjnej kraju utrzymane były na odpowiednim poziomie. Natomiast o wiele bardziej absorbującym dla nich problemem był nieuzasadniony wzrost cen (drożyzna), który uderzał w podstawy egzystencji najuboższych warstw społeczeństwa. W dniu 29 kwietnia 1936 r. minister spraw wewnętrznych W. Raczkiewicz wydał reskrypt, w którym nakazywał władzom administracji ogólnej kontrolowanie

${ }^{30}$ Ibidem, sygn. 477, Sprawa organizacji „Państwowych Zakładów Przemysłowo-Zbożowych” z siedzibą w Lublinie, k. 6-7; L. BilıP, Mąka i pieczywo, Warszawa 1930, s. 7-15.

${ }^{31}$ W. Kozyra, Polityka administracyjna..., s. 496; R. Hausner, op. cit., s. 45.

32 Vide: W. Kozyra, Polityka administracyjna..., s. 21-220.

${ }^{33}$ Dziennik Ustaw 1938, nr 13, poz. 89; R. Hausner, op. cit., s. 45. 
wzrostu cen artykułów żywnościowych. W jego wyniku, wojewoda poznański Artur Maruszewski zarządził, by starostowie osobiście interesowali się „kwestią równowagi między cenami surowców i gotowych artykułów żywności”. W razie jej zachwiania, mieli obowiązek przystąpić do ustalenia cen w drodze urzędowej. Powinni też przesyłać do urzędu wojewódzkiego miesięczne sprawozdania informacyjne, mówiące o ruchu cen $\mathrm{w}$ powiecie, o wydanych zarządzeniach wraz z aktualnym wykazem cen artykułów powszechnego użytku. W kolejnym piśmie, A. Maruszewski nakazywał starostom szczegółowe poznawanie cen artykułów pierwszej potrzeby, „i to z dnia na dzień”. Następnie, stosowanie wszelkich środków prawnych celem niedopuszczenia do wzrostu cen, a w szczególności wzrostu wynikającego z działalności spekulacyjnej; skuteczne karanie winnych spekulacji cenowych oraz zwalczania lichwy cenowej. Ich obowiązkiem było też dokonywanie własnych kalkulacji cenowych w celu zorientowania się w realnych cenach poszczególnych produktów żywnościowych na podległym im terenie ${ }^{34}$.

Wojewoda lubelski Józef Różniecki w sprawozdaniu za lata 1936-1937 informował MSW, że podległe mu organy administracji ogólnej obserwowały kształtowanie się cen artykułów powszechnego użytku w zależności od zmieniających się na rynku gospodarczym cen surowców i kosztów ich przetwarzania. W drugiej połowie 1936 r. ceny te ustabilizowały się już tak, że starostowie nie uciekali się do urzędowego ich ustalania, a jedynie kontrolowali je w drodze porozumień z poszczególnymi branżami wytwórczymi. Z początkiem $1937 \mathrm{r}$. nastąpił jednak ponowny wzrost cen zbóż chlebowych, co wywołało od razu lichwę cenową na produkty żywnościowe. Zareagowały natychmiast organy administracji rządowej, wyznaczając, po konsultacji z Wojewódzką Komisją Badania Cen, urzędowe ceny na produkty zbożowe ${ }^{35}$. Przeciętne ceny podstawowych surowców oraz produktów żywnościowych na Lubelszczyźnie w 1936 r. ukazuje tabela 2. Natomiast przeciętny ruch cen w ujęciu procentowym w województwie lubelskim w $1936 \mathrm{r}$. w porównaniu do $1935 \mathrm{r}$. przedstawia tabela 3.

Z tabel tych wynika, że w latach 1935-1936 ruch cen poszczególnych surowców i produktów spożywczych w Lubelskiem nie był ustabilizowany i charakteryzował się tendencją wzrostową. Podobna sytuacja była i w innych regionach kraju, np. w Łódzkiem. W lutym 1937 r. wojewoda łódzki Aleksander Hauke-Nowak, znaczną część zjazdu starostów poświęcił kwestiom aprowizacyjnym, a w szczególności walce ze wzrostem cen na artykuły pierwszej potrzeby ${ }^{36}$.

${ }^{34}$ Archiwum Państwowe w Poznaniu (dalej: APP), Urząd Wojewódzki Poznański, Wydział Ogólny, sygn. 127, Reskrypt ministra spraw wewnętrznych Władysława Raczkiewicza z 29 IV 1936 r., k. 35 i Pismo wojewody poznańskiego Artura Maruszewskiego do starostów z 19 V 1936 r., k. 61.

35 APL, Urząd Wojewódzki Lubelski, Wydział Ogólny, sygn. 274, Sprawozdanie wojewody lubelskiego za lata 1936-937, k. 87.

${ }^{36}$ Zjazd starostów województwa łódzkiego, „Gazeta Polska” 1937, nr 66 z 7 II 1937 r. 
Tabela 2

Przeciętne ceny w złotych podstawowych surowców i produktów żywnościowych na Lubelszczyźnie w 1936 r.

\begin{tabular}{|c|c|c|c|c|c|c|c|c|}
\hline 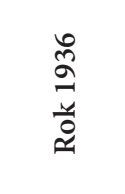 & 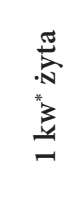 & 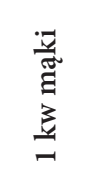 & $\begin{array}{l}\frac{\pi}{0} \\
\frac{0}{1} \\
0 \\
* 00 \\
=1\end{array}$ & 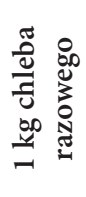 & 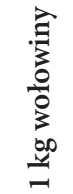 & 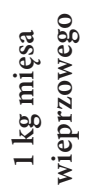 & 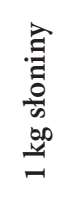 & 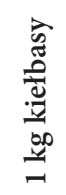 \\
\hline kwiecień & 12,21 & 20,62 & 0,23 & 0,15 & 0,80 & 1,08 & 1,45 & 1,56 \\
\hline czerwiec & 13,38 & 21,93 & 0,24 & 0,17 & 0,88 & 1,30 & 1,63 & 1,73 \\
\hline wrzesień & 13,25 & 22,43 & 0,24 & 0,16 & 0,92 & 1,30 & 1,59 & 1,71 \\
\hline grudzień & 16,67 & 27,84 & 0,28 & 0,19 & 0,82 & 1,26 & 1,57 & 1,66 \\
\hline
\end{tabular}

${ }^{*} \mathrm{kw}$ - kwintal; ${ }^{* *} \mathrm{~kg}$ - kilogram

Źródło: Archiwum Państwowe w Lublinie, Urząd Wojewódzki Lubelski, Wydział Ogólny, sygn. 274, s. 88, Sprawozdanie wojewody lubelskiego za lata 1936-1937.

Tabela 3

Przeciętny ruch cen w procentach na Lubelszczyźnie w 1936 r. w porównaniu do $1935 \mathrm{r}$.

\begin{tabular}{|c|c|c|c|c|c|c|c|c|}
\hline 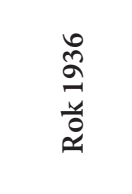 & 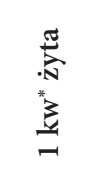 & 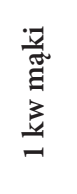 & 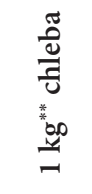 & 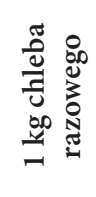 & 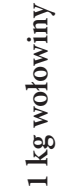 & 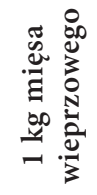 & 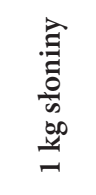 & 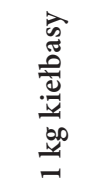 \\
\hline kwiecień & $-5,2$ & $-6,4$ & $-5,0$ & $-6,0$ & $-3,6$ & $+10,2$ & $+34,2$ & $+10,6$ \\
\hline czerwiec & $\mathrm{bd}^{* * *}$ & $-2,5$ & $-4,0$ & $+5,5$ & $+7,3$ & $+36,6$ & $+57,7$ & $+21,8$ \\
\hline wrzesień & $+24,2$ & $+2,4$ & $+4,3$ & $+6,6$ & $-3,2$ & $-7,1$ & $-12,6$ & $-13,2$ \\
\hline grudzień & $+5,0$ & $+4,2$ & $+27,2$ & $+26,6$ & bd & $+9,5$ & $-3,0$ & $-0,6$ \\
\hline
\end{tabular}

${ }^{*} \mathrm{kw}$ - kwintal; **kg - kilogram; ***bd - brak danych

Źródło: Archiwum Państwowe w Lublinie, Urząd Wojewódzki Lubelski, Wydział Ogólny, sygn. 274, s. 88, Sprawozdanie wojewody lubelskiego za lata 1936-1937. 
W 1937 r. minister spraw wewnętrznych wydał znaczną ilość zarządzeń i pism przewodnich, mających na celu poprawę trudnej sytuacji aprowizacyjnej kraju. Ukazały się okólniki i pisma dotyczące uregulowania cen przetworów zbóż chlebowych, nowego sposobu wyznaczania cen artykułów mącznych, uregulowania cen mąki i pieczywa. Wydał także wytyczne w sprawie sposobu prowadzenia kontroli ruchu cen artykułów żywnościowych i decyzja w sprawie utworzenia ogólnopaństwowej Komisji Kontroli Cen. W styczniu 1938 r. minister spraw wewnętrznych S.F. Składkowski - w porozumieniu z ministrem skarbu Eugeniuszem Kwiatkowskim - wydał zarządzenie, w którym wyrażał zgodę na to, by wojewodowie w drodze wyjątku mieli prawo podnieść cenę detaliczną cukru, nie wyższą jednak, niż 1,05 zł za kilogram. Można ją było podnieść, gdyby w sposób znaczący zwiększyły się koszty transportu tegoż produktu na teren województwa, a w związku z tym zmniejszyłyby się zyski przedsiębiorstw handlowych i powstała groźba wywołania niepotrzebnych perturbacji gospodarczych oraz społecznych ${ }^{37}$.

Po kilku latach dyskusji nad miejscem i rolą spraw aprowizacyjnych w państwie, Rada Ministrów podjęła 16 lutego 1938 r. uchwałę o wyłączeniu spraw aprowizacyjnych $z$ kompetencji ministra spraw wewnętrznych i przekazaniu ich ministrowi rolnictwa i reform rolnych. Na jej podstawie, prezydent RP wydał wspomniany dekret z 22 lutego 1938 r. Proces przekazywania przez resort spraw wewnętrznych służb aprowizacyjnych resortowi rolnictwa, rozpoczął się w marcu tego roku. W tym czasie, minister rolnictwa i reform rolnych Juliusz Poniatowski zaproponował, by utworzyć komisję międzyresortową, która nadzorowałaby przekazywanie agend aprowizacyjnych podległej mu administracji, a zarazem przekazała środki finansowe na ich utrzymanie ${ }^{38}$. Ostatecznie, Biuro Aprowizacyjne MSW weszło w połowie 1938 r. w skład Ministerstwa Rolnictwa i Reform Rolnych, a zmiany na szczeblu terenowym rozpoczęły się jesienią tego roku. Wojewoda krakowski Józef Tymiński wydał zarządzenie, w myśl którego 1 listopada 1938 r. w Urzędzie Wojewódzkim Krakowskim miał zostać zlikwidowany istniejący dotąd w Wydziale Samorządowym Oddział Aprowizacyjny, a jego agendy przeszły do Wydziału Rolnictwa i Reform Rolnych - w jego składzie utworzyć miano nowy Oddział Aprowizacyjny. W powiatach natomiast sprawy aprowizacyjne powinny być prowadzone przez urzędy gminne - do czasu utworzenia w starostwach referatów aprowizacyjnych. Odtąd, w latach 1938-1939 administracja spraw wewnętrznych zajmowała się sprawami ochrony lokatorów,

${ }^{37}$ APP, Urząd Wojewódzki Poznański, Wydział Ogólny, sygn. 129, Zarządzenia ministra spraw wewnętrznych i ministra skarbu w sprawach aprowizacyjnych. k. 5.

38 AAN, MSW, Gabinet Ministra - Sekretariat Ministra, sygn. 836, Uchwała Rady Ministrów z 16 II 1938 r. o wyłączeniu spraw aprowizacyjnych z kompetencji ministra spraw wewnętrznych i przekazaniu ich ministrowi rolnictwa i reform rolnych, k. 13. 
zwłaszcza nadorowała ceny kwaterunku. Jednocześnie wspierała działalność Ministerstwa Rolnictwa i Reform Rolnych w zakresie spraw aprowizacyjnych, w szczególności czyniły to Biuro Wojskowe MSW, wydziały wojskowe w urzędach wojewódzkich i referaty wojskowe w starostwach w zakresie mobilizacji gospodarczej dla celów wojskowych ${ }^{39}$.

\section{Wydatki budżetowe na Wojsko Polskie i jego aprowizację w latach 1918-1939}

Należy skonstatować, że polityka administracyjna resortu spraw wewnętrznych w zakresie aprowizacji miała pośredni, ale bardzo ważny, wpływ na aprowizację armii polskiej. Szybko okazało się, iż mimo poważnych przeksztalceń koncepcyjnych i organizacyjnych w strukturach aprowizacyjnych państwa, zwłaszcza w latach 1918-1921, ale też i późniejszych, np. 1923-1924, 1934-1935 oraz 19381939, które sprawiały wrażenie pewnego chaosu organizacyjnego - armia polska była stale aprowizowana. Szybko też okazała się jednym ze stabilniejszych podsystemów aprowizacyjnych $\mathrm{w}$ państwie, funkcjonującym $\mathrm{z}$ roku na rok coraz sprawniej i lepiej. Należy przypomnieć, że wydatki państwa na armię i jej utrzymanie były bardzo wysokie przez cały okres międzywojenny. Tak więc, w okresie 1919-1920 budżety wojskowe kształtowały się na poziomie 50-60\% wydatków państwa. Jeżeli do tego dodamy pożyczki i kredytowe dostawy zagraniczne - to łącznie wydatki wojskowe osiągnęły $70 \%$ wydatków państwa. Po przejściu armii na stopę pokojową, kwoty finansowe na jej utrzymanie znacząco spadły. Tak więc w latach 1921-1931 (w których wydatki wojskowe stanowiły niemal wyłącznie środki budżetowe) kwoty wydane na wojsko kształtowałty się w granicach 30-33\% wszystkich wydatków budżetowych państwa. W liczbach bezwzględnych było to np. w 1925 r. - 747,2 mln zł, w 1928/1929 - 948,6 mln zł, w 1930/1931 - 866,2 mln zł ${ }^{40}$. Od 1931 r. nastąpił sukcesywny wzrost wydatków na armię polską. Wpłynęły na to dwa zasadnicze czynniki. Pierwszy z nich to polityka deflacyjna rządów sanacyjnych w latach wielkiego kryzysu gospodarczego oraz realizowana od 1936 r. przez te rządy polityka rozbudowy i modernizacji armii. Tak więc po 1931 r., w wyniku spadku cen produktów rolnych i przemysłowych, $\mathrm{z}$ jednoczesnym utrzymaniem sztywnego kursu złotego do dolara i jego wymienialności na złoto do 1936 r., wydatki na wojsko wzrosły o $40-45 \%$. Należy przypomnieć, że w 1924 r. wartość 1 dolara równała się 5,18 zł, by następnie spaść w 1925 r. do kursu: 1 dolar - 9,10 zł. Jednakże w okresie wzrostu gospodarczego

${ }^{39}$ Archiwum Państwowe w Krakowie, Urząd Wojewódzki Krakowski, Wydział Wojskowy, sygn. 108, Okólnik wojewody krakowskiego z 28 X 1938 r., bez paginy; Biblioteka Uniwersytetu Jagiellońskiego, K.M. SzerląG, Mój pamiętnik z dlugich lat życia mego (okres 1919-1939), sygn. 47/78, s. 79, 81, 86.

${ }^{40}$ K. Krzyżanowski, Wydatki wojskowe Polski w latach 1918-1939, Warszawa 1976, s. 176. 
z lat 1926-1929, kurs złotego do dolara ustabilizował się w relacji 1 dolar - 8,91 zł i w wyniku deflacyjnej polityki rządu utrzymał się prawie niezmienionym poziomie do 1939 r. Dalsze znaczące zwiększenie budżetu wojskowego nastąpiło w latach 1936-1939. I tak, w roku budżetowym 1936-1937 budżet wojskowy wynosił $768 \mathrm{mln}$ zł, ale inne wydatki państwa na cele wojskowe podnosiły tę kwotę do sumy 1,05 mld zł. Natomiast w roku budżetowym 1938-1939 na potrzeby wojska przeznaczono $832,4 \mathrm{mln} \mathrm{zl}$, ale łączne wydatki państwa na wojsko wynosiły aż 1,35 mld $\mathrm{zt}^{41}$.

Biorąc całość sum budżetowych wydatkowanych na WP w okresie międzywojennym (19,33 mld zł) za 100\% - to na zasadnicze działy przeznaczono: a) około $80 \%$ na bieżące utrzymanie i wyposażenie sił zbrojnych; b) $12 \%$ na rezerwy zaopatrzenia armii; c) około 4\% na przemysł zbrojeniowy i budownictwo; d) około $4 \%$ na inne wydatki. W każdej z tych grup znajdowały się kwoty przeznaczone na różnego rodzaju zapotrzebowania aprowizacyjne. Jednakże, najwięcej wydatkowano z działu - bieżące utrzymanie i wyposażenie sił zbrojnych, które powszechnie nazywano „wydatkami wegetacyjnymi”; stanowiły one około 40\% wszystkich wydatków tej grupy. Ich struktura była następująca: wydatki ściśle wegetacyjne (aprowizacja żywnościowa ludzi i zwierząt) - 50\%, wydatki materiałowe (szeroko rozumiany sprzet i produkty pierwszej potrzeby) - $40 \%$ oraz wydatki administracyjno-biurowe $-10 \%{ }^{42}$. W liczbach bezwzględnych wydatki wegetacyjne wynosiły - wybrane lata (tabela 4).

Tabela 4

Wydatki budżetowe wojska na cele wegetacyjne (wybrane lata)

\begin{tabular}{|c|c|c|c|c|c|c|c|c|}
\hline 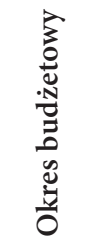 & 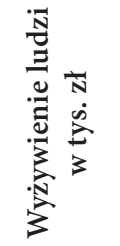 & 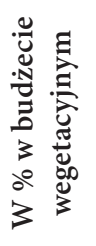 & 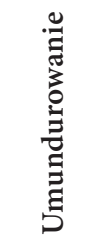 & 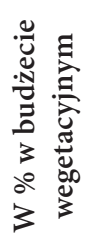 & 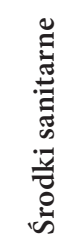 & 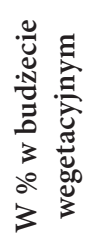 & 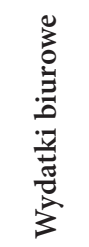 & 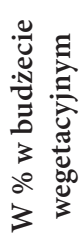 \\
\hline 1925 & 127793 & 31,1 & 44340 & 10,5 & 3905 & 0,9 & 3923 & 0,9 \\
\hline $\begin{array}{l}1927 / \\
1928\end{array}$ & 115834 & 24,7 & 29887 & 7,4 & 2910 & 0,7 & 3515 & 0,8 \\
\hline
\end{tabular}

${ }^{41}$ Ibidem, 176-177; R. JAStrzęBSkI, Polityka deflacyjna II Rzeczypospolitej a prawo lat trzydziestych XX wieku, „Studia z Dziejów Państwa i Prawa Polskiego” 2013, t. XVI, s. 272-275.

${ }^{42}$ K. KrzyŻanOWsKi, op. cit., s. 177. 
Tabela 4 (cd.)

\begin{tabular}{|c|c|c|c|c|c|c|c|c|}
\hline $\begin{array}{l}0 \\
0 \\
0 \\
0 \\
-N \\
0 \\
0 \\
0 \\
0 \\
0 \\
0 \\
0 \\
0\end{array}$ & 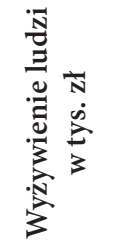 & 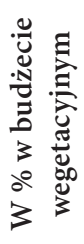 & 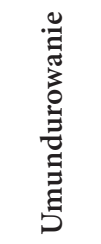 & 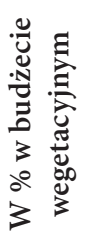 & 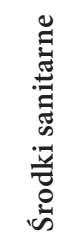 & 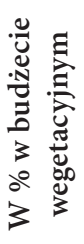 & 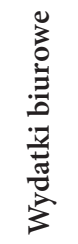 & 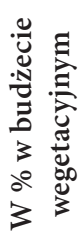 \\
\hline $\begin{array}{l}1929 / \\
1930\end{array}$ & 151428 & 26,7 & 46480 & 8,2 & 3472 & 0,7 & 2476 & 0,5 \\
\hline $\begin{array}{l}1931 / \\
1932\end{array}$ & 68260 & 13,0 & 35975 & 8,6 & 3571 & 0,7 & 6291 & 1,2 \\
\hline $\begin{array}{l}1931 / \\
1932\end{array}$ & 55000 & 13,1 & 29200 & 9,6 & 3564 & 0,8 & 3028 & 0,7 \\
\hline $\begin{array}{l}1935 / \\
1936\end{array}$ & 59410 & 14,7 & 25921 & 7,6 & 3353 & 0,7 & 2512 & 0,6 \\
\hline $\begin{array}{l}1937 / \\
1938\end{array}$ & 98102 & 19,6 & 39200 & 7,8 & 3800 & 0,9 & $b^{*}$ & bd \\
\hline $\begin{array}{l}1938 / \\
1939\end{array}$ & 68000 & 14,2 & 38340 & 7,6 & 3640 & 0,8 & 1800 & 0,4 \\
\hline
\end{tabular}

*bd - brak danych

Źró dło: opracowano na podstawie: K. KRzYŻAnowski, Wydatki wojskowe Polski w latach 1918-1939, Warszawa 1976, s. 185.

\section{Podsumowanie}

Należy stwierdzić, że w II RP w latach 1918-1939 naczelnymi instytucjami państwa w zakresie aprowizacji były: w latach 1918-1921 Ministerstwo Aprowizacji, w latach 1921-1938 MSW, a w latach 1938-1939 Ministerstwo Rolnictwa i Reform Rolnych. Oczywiście, w całym okresie międzywojennym na rzecz aprowizacji państwa, a zwłaszcza jego zasadniczych podsystemów aprowizacyjnych, takich jak ludność miejska (różne kategorie miast i osiedli), ludność wiejska (poszczególne regiony kraju), armia, administracja publiczna, zakłady przemysłowe, przedsiębiorstwa państwowe, itp. - pracowało wiele wyspecjalizowanych instytucji państwowych (administracyjnych), struktur samorządowych, podmiotów gospodarczych, organizacji społecznych. Jednakże, co należy podkreślić z całą mocą, koncepcje polityki aprowizacyjnej, a następnie formy i metody jej 
realizacji, powstawały w naczelnych i centralnych instytucjach państwa, które z mocy ustaw i rozporządzeń rządowych posiadały kompetencje w tym zakresie. Należy przypomnieć, że przez znakomitą część okresu międzywojennego naczelną instytucją państwa $\mathrm{w}$ dziedzinie polityki aprowizacyjnej było MSW. Dlatego też, bez poznania meandrów polityki administracyjnej ministrów spraw wewnętrznych w sprawach aprowizacyjnych, nie można zrozumieć sposobów aprowizacji społeczeństwa w okresie II RP, a zwłaszcza form, metod i problemów związanych z aprowizacją WP.

W prezentowanym wystąpieniu polityka administracyjna resortu spraw wewnętrznych w zakresie aprowizacji została - zgodnie z historią polityczną II RP - podzielona na cztery okresy: 1918-1926, 1926-1930, 1930-1935 oraz 1935-1939. W pierwszym $z$ nich, resort spraw wewnętrznych, a zwłaszcza jego struktury terenowe (urzędy wojewódzkie, starostwa), jak też nadzorowane przez niego struktury samorządu terytorialnego (zwłaszcza zarządy miejskie i urzędy gminne) - ściśle współpracowały z Ministerstwem Aprowizacji, którego agendy terenowe znajdowały się w strukturach administracji spraw wewnętrznych i samorządu terytorialnego. Natomiast od 1921 r., kiedy to zlikwidowano urząd ministra aprowizacji, a jego zasadnicze uprawnienia przejął minister spraw wewnętrznych, politykę aprowizacyjną państwa kształtowało i realizowało kierownictwo administracji spraw wewnętrznych. W latach 1921-1926 jego działania koncentrowały się w pierwszej kolejności na zapewnieniu żywności i szeroko rozumianych produktów pierwszej potrzeby całemu społeczeństwu, a zwłaszcza ośrodkom miejskim. Po wejściu w życie reformy walutowej premiera W. Grabskiego w kwietniu 1924 r. i wprowadzeniu złotego polskiego (w miejsce marki polskiej), szybko z życia społeczno-gospodarczego zniknął problem drożyzny, lecz pojawiły się ponownie braki w zaoparzeniu ludności w produkty żywnościowe i artykuły pierwszej potrzeby. W konsekwencji, koncepcje polityki aprowizacyjnej MSW uległy zmianie, zaś w pionie aprowizacyjnym resortu spraw wewnętrznych nastąpiła ponowna, poważna reorganizacja.

W latach 1926-1930, czyli w pierwszym okresie po zamachu majowym $1926 \mathrm{r}$., następuje znaczące uporządkowanie spraw aprowizacyjnych w państwie, poprzez poważne zmodyfikowanie dotychczasowej polityki administracyjnej resortu spraw wewnetrznych w dziedzinie aprowizacyjnej. Dzięki temu, kierownictwo resortu spraw wewnętrznych skoncentrowało się na zabezpieczeniu w kraju produkcji zbożowej, w szczególności zboża chlebowego, którego rezerw praktycznie nie było. W wyniku uaktywnienia działań Państwowego Banku Rolnego, już na przełomie lat 1928-1929 utworzono Państwową Rezerwę Zbożową, która z roku na rok coraz lepiej zabezpieczała kraj przed brakami żywności, a jednocześnie pozytywnie oddziaływała na ceny zbóż chlebowych, które znacząco 
spadały. Zaczęto też pracować na rzecz podniesienia poziomu aprowizacji kraju w mięso i jego przetwory. Aparat aprowizacyjny MSW współdziałał z wieloma instytucjami rządowymi i samorządowymi na rzecz tworzenia w stolicy kraju centralnych instytucji gospodarczo-aprowizacyjnych, takich jak: Giełda Mięsna, Kasa Targowa czy Targowica Centralna, które rozpoczęły pracę już wiosną 1929 r. $\mathrm{W}$ ścisłym związku ze sprawą zaopatrywania ludności w mięso, ale również w nabiał i jaja, przygotowywano plany budowy nowoczesnych chłodni w głównych ośrodkach przemysłowych kraju.

W latach 1930-1935 celem ministrów spraw wewnętrznych i podległej im administracji aprowizacyjnej było działanie na rzecz obniżenia kosztów utrzymania szerokich grup ludności, odczuwających wielki kryzys gospodarczy. Jednocześnie, w tym czasie rozpoczęła się dyskusja nad nowym ustyuowaniem administracji aprowizacyjnej w strukturze administracyjnej państwa. Ostatecznie jednak, naczelnym organem $\mathrm{w}$ sprawach aprowizacji państwa pozostał minister spraw wewnętrznych. W latach 1935-1939 szefowie resortu spraw wewnętrznych politykę aprowizacyjną wykonywali poprzez tworzenie państwowej rezerwy aprowizacyjnej, w szczególności zbożowej oraz zwalczanie drożyzny artykułów powszechnego użytku. Politykę tę wykonywali formalnie do 22 lutego 1938 r., kiedy to sprawy aprowizacji państwa przeszły w gestię minstra rolnictwa i reform rolnych. Z resortu spraw wewnętrznych, tak w centrali, jak i w terenie, sukcesywnie w ciągu 1938 r. wyłączano komórki organizacyjne zajmujące się aprowizacją i przekazywano je do struktur podledłych Ministerstwu Rolnictwa i Reform Rolnych. Odtąd, administracja spraw wewnętrznych (1938-1939) w bardzo ograniczonym zakresie pracowała na rzecz spraw aprowizacyjnych.

W artykule zaprezentowano też skalę wydatków II RP na armię polską, w szczególności na jej aprowizację. Należy przypomnieć, że budżet MSW był największym ze wszystkich budżetów resortowych. Wojsko Polskie było więc jednym z największych i najważniejszych podsystemów aprowizacyjnych państwa. Ostatecznie należy skonstatować, że system aprowizacyjny państwa polskiego - i to od początku jego istnienia - uniósł, choć nieraz z trudem, nie tylko ciężar zaaprowizowania społeczeństwa polskiego w żywność i artykuły pierwszej potrzeby, ale też aprowizację armii polskiej, tak w okresie wojen (1918-1921), jak i w czasie pokoju (1921-1939). 


\title{
Waldemar Kozyra
}

\section{ADMINISTRATIVE POLICY OF THE INTERIOR MINISTERS OF THE REPUBLIC OF POLAND IN THE FIELD OF PROVISIONING AND ITS IMPACT ON THE PROVISIONING OF THE POLISH ARMY IN 1918-1939}

\begin{abstract}
Summary: It should be noted that in the Republic of Poland in the years 1918-1939 the main state institutions in the field of provisioning were: in the period of 1918-1921 the Ministry of Provisioning, in the years 1921-1938 the Ministry of the Interior, and in the years 1938-1939 the Ministry of Agriculture and Agricultural Reforms. Of course, in the entire interwar period for the provision of state supplies, and especially its main supply subsystems, such as urban population (various categories of cities and settlements), rural population (individual regions of the country), Polish army, public administration, state enterprises, industrial plants, etc. many specialized state (administrative) institutions, self-government structures, business entities and social organizations worked. However, it should be emphasized with all force that the concepts of the provisioning policy, and then the forms and methods of its implementation arose in the central and supreme institutions of the state, which, by virtue of government laws and ordinances, received competences in this respect. It should be recalled that for a great part of the interwar period the supreme state institution in the field of food supply policy was the Ministry of the Interior. Therefore, without knowing the twists and turns of the administrative policy of the Interior Ministers in the field of food supply, it is impossible to understand the ways of provisioning the society during the Second Polish Republic, and especially the forms, methods and problems related to the provisioning of the Polish Army. Finally, it should be noted that the provisioning system of the Polish State - starting from its very beginning - has although sometimes with difficulty, coped with not only the burden of provisioning the Polish society with food and necessities, but also the provisioning of the Polish army during the wars (1918-1921), during peace (1921-1939) as well as during the German-Polish war of 1939.
\end{abstract}

Keywords: provisioning, Ministry of Provisioning, Ministry of the Interior, Independent Approval Department, Approval Office, Polish Army, vegetative expenses, food, necessities. 